\title{
INFLUENCE OF PROGESTIN SOURCE ON SOME BLOOD BIOCHEMICAL CONSTITUENTS OF DROMEDARY SHE-CAMELS DURING INDUCTION OF OVULATION IN THE NORTH WESTERN COAST OF EGYPT
}

\author{
I. S. Abd-El Hamid ${ }^{3}$, A. A. Zaghloul ${ }^{3}$, K. A. El-Bahrawy ${ }^{3}$, S. Z. El-Zarkouny ${ }^{1,2}$ \\ ${ }^{1}$ Department of Arid Land Agriculture, Faculty of Meteorology, Environment and Arid Land Agriculture, King \\ Abdul-Aziz University Jeddah, Saudi Arabia \\ ${ }^{2}$ Department of Animal and Fish Production, Faculty of Agriculture, Alexandria University, Alexandria, Egypt \\ ${ }^{3}$ Animal and Poultry Production Division, Desert Research Center Cairo, Egypt
}

SUMMARY

\begin{abstract}
Eighteen one-humped she-camels were divided randomly into three equal groups: group 1 served as control; group 2 (MGA) received $(0.5 \mathrm{mg} /$ head/day) of Melengestrol acetate for 10 days and; group 3 (CIDR) were fitted intravaginally with controlled internal drug release (CIDR, $\left.1.38 \mathrm{~g} P_{4}\right)$ for 10 days. At day 10 the MGA and CIDR groups were administered PGF $F_{2 \alpha}$ and 3000 IU PMSG, MGA feeding was withdrawn and CIDRs were removed. Animals were given 5000 IU of hCG 10 days later and were artificially inseminated (day 20). Blood samples were collected from all groups at day $O=$ day of CIDR insertion and beginning of MGA feeding; day $5=5$ days after $C I D R$ insertion and onset of MGA feeding; day 10 = day of CIDR removal and MGA feeding withdrawal; and day $20=$ day of hCG injection. Serum biochemical and mineral constituents, and serum reproductive hormones (estradiol-17 $\beta$ and progesterone) were determined. Overall means of serum concentrations of total protein, albumin, cholesterol, and AST enzyme were not different among treatments. Treatment with CIDR increased BUN at days 10 and 20 and the overall mean BUN concentration compared to control and MGA groups. Treatments with CIDR and MGA numerically increased serum glucose compared to control at days 10 and 20. However, overall mean serum concentrations of HDL were not affected by CIDR and treatments. In the meantime, CIDR and MGA increased serum ALT concentrations at days 20 and the overall means ALT concentrations compared to control. No marked changes were detected in serum concentrations of $\mathrm{Ca}^{++}$and $\mathrm{Na}^{+}$in the MGA and CIDR groups compared to controls. Serum concentrations of $K^{+}$were increased at day 20 in the MGA and CIDR groups than at days 0 and 5. Overall mean serum concentration of $K^{+}$was greater in the CIDR group $(4.2 \pm 0.14 \mathrm{mEq} / \mathrm{l})$ than in control (3.4 \pm $0.16 \mathrm{mEq} / \mathrm{l})$ and MGA (3.5 $\pm 0.14 \mathrm{mEq} / \mathrm{l})$ groups. Similar trend was detected in serum concentrations of $P$ as MGA and CIDR groups had more $(P<0.01)$ serum $P(4.7 \pm 0.36$ and $4.6 \pm 0.24 \mathrm{mg} / \mathrm{dl})$ at days 20 compared to days 0,5 and 10. Results also indicated that natural progestin treatment $(C I D R)$ increased $P_{4}$ concentration at days 5 and 10 while control and MGA-fed animals had lower $P_{4}$ levels. Also, CIDR increased the overall mean $P_{4}$ concentration $(2.9 \pm 0.28 \mathrm{ng} / \mathrm{ml})$ compared to control and MGA groups $(0.5 \pm 0.33$ and $0.9 \pm 0.29 \mathrm{ng} / \mathrm{ml})$. Both MGA and CIDR groups had lower estradiol at days 5 and 10. At day 20, estradiol was elevated in the CIDR group compared to control and MGA groups. In conclusion, progestin treatments exerted no deleterious effects on animal health and can be used without limitation for further treatments. Natural $P_{4}$ improved the pattern of reproductive hormones secretion without detrimental effects on animal health and blood biochemical constituents.
\end{abstract}

Keywords: Camels, progesterone, minerals, serum

\section{INTRODUCTION}

Camels (Camelus dromedarius) play a very important and vital role in the economy and social life of a large sector of pastoralists in arid, semi-arid, subtropical and tropical regions in several localities in the world. Camels (Camelus dromedarius) importance stems from serving as a valuable nutrient resource for meat and milk for humans (Farah, 1996). However, fewer reports have been published studying different normal, physiological and pathological conditions on blood parameters of camel (Osman and Busadah, 2000). Blood and mineral concentrations in camel plasma might be a potential aid in characterizing the different physiological problems. Blood biochemical measurements are frequently used because they are significantly correlated with the nutritional status of some trace minerals (Claypool et al., 1975). Therefore, studies about the biochemical constituents and minerals concentrations are very important for clinicians in the field during different reproductive phases including estrous cycle, synchronization programs, artificial insemination and embryo transfer as they utilize the progestin sources for treatments (Skidmore et al., 2009). Methods of administration of progesterone include daily injection, melengestrol acetate (MGA) oral consumption, controlled intravaginal drug release (CIDR) and subcutaneous implants (Thomposon, 2001). Commercial preparations of progesterone designed primarily for use in cattle are currently being used in the camels without adequate pharmacokinetic information (Al-Busadah and Homeida, 2004). Unfortunately intravaginal progesterone inserts containing natural progesterone (CIDR) are not successfully retained intravaginally in she-camels 
roaming vast and rugged terrains. The present study aimed to study the effect of administration of natural source of progesterone (CIDR) vs. synthetic (MGA) source of progesterone on some serum biochemical and mineral constituents in dromedary she-camel.

\section{MATERIALS AND METHODS}

This study was carried out at Maryout Research Station located $34 \mathrm{~km}$ west of Alexandria belonging to the Desert Research Center (DRC), Ministry of Agriculture, and at the Department of Animal Production, Faculty of Agriculture, and Alexandria University.

\section{Animal's management}

Eighteen mature one-humped she-camels aged 710 years with average body weights of $450 \pm 20 \mathrm{~kg}$ were used in this study. The animals were housed in closed pens throughout the experimental period. Shecamels were fed a concentrate mixture according to their body weight requirements (NRC, 1985). All animals were given Egyptian clover (Trifolium alexandrinum) hay as a roughage ration and grassing ad lib. Each animal also received $4 \mathrm{~kg}$ per day of pelleted concentrate mixture that contained $65 \%$ total digestible nutrients (TDN) and 14\% crude protein. Fresh water was presented twice daily. Animals were examined clinically and were found to be free of any disease, physical abnormalities or reproductive disorders.

\section{Experimental design}

The present study aimed to study the effect of administration of natural source of progesterone (CIDR) vs. synthetic (MGA) source of progesterone on some serum biochemical constituents in dromedary she-camels during synchronization of ovulation period. Eighteen one-humped she-camels were divided into three equal groups: The first group: control $(n=6)$ served as control. The second group: (MGA, $n=6)$ received $(0.5 \mathrm{mg} / \mathrm{head} /$ day $)$ of Melengestrol acetate (MGA® 200 Premix NDC 0009 - 0952 - 01, Upjohn Company; Michigan, USA) for 10 days. The Third group: (CIDR, $n=6)$ were fitted intravaginally with controlled internal drug release (CIDR, $1.38 \mathrm{gm}$ ) insert (EAZI-BREED, InterAg, Hamilton, New Zealand) for 10 days. The chemical composition of (MGA) is presented in Table (1).

\section{Meteorological data:}

Meteorological data including relative humidity $(\mathrm{RH}, \%)$ and air temp (AT, $\left.{ }^{\circ} \mathrm{C}\right)$, were obtained from a Climatological Station located in Nubaria Research Station, Ministry of Agriculture and Land Reclamation. Temperature-Humidity Index (THI) was calculated according to the equation proposed by Amundson et al. (2006). $\mathrm{THI}=(0.8 \times$ temperature $)+[(\%$ relative humidity/100) $\times($ temperature-14.4) $]+$ 46.4. Mean values of these parameters are presented in Table (2).

Table 1. Chemical composition of Melengestrol Acetate 200 Premix (MGA)

\begin{tabular}{lccc}
\hline Inactive Ingredients & $(\boldsymbol{\%})$ & Active Drug Ingredient & mg/lb \\
\hline Soybean hulls & 96 & Melengestrol Acetate & 200 \\
Mineral Oil & 2.98 & - & - \\
\hline
\end{tabular}

Table 2. Changes in means of ambient temperatures, relative humidity and temperature-humidity index (THI) throughout the experimental period in she-camels

\begin{tabular}{cccc}
\hline Days & $\begin{array}{c}\text { Air temperature } \\
\left({ }^{\circ} \mathrm{C}\right)\end{array}$ & $\begin{array}{c}\text { Relative humidity } \\
(\%)\end{array}$ & $\begin{array}{c}\text { Temperature-Humidity } \\
\text { Index (THI) }\end{array}$ \\
\hline 0 & 25.5 & 89 & 76.6 \\
5 & 21.5 & 99 & 70.7 \\
10 & 24.7 & 90 & 75.4 \\
20 & 21.0 & 93 & 70.4 \\
\hline
\end{tabular}

\section{Blood samples}

Blood samples were collected from the jugular veins of all animals in vacutainer tubes before and after supplementation of Melengestrol acetate (MGA) and CIDR treatment at day $(0)=$ day of CIDR insertion and beginning of MGA feeding; day $5=5$ days after CIDR insertion / start of MGA feeding; day 10 = day of CIDR removal or MGA feeding withdrawal; and day 20 = day of hCG injection). Serum was harvested after centrifugation at 3,000 rpm for 20 minutes, and then stored at $-20{ }^{\circ} \mathrm{C}$ for later analysis.

\section{Serum biochemical analysis:}

Sera samples from she-camels during the experimental period were subjected to colorimetric analysis using commercial kits. Concentrations of total protein (TP), cholesterol (CHO), high density lipoprotein (HDL), albumin (A) and blood urea nitrogen (BUN) were determined using colorimetric 
kits (STANBIO LABORATORY). Alanine amino taransferase (ALT) and aspartate amino taransferase (AST) were determined using colorimetric kits (QCA, USA). Glucose (Glu) was determined using colorimetric kits (Diamond Diagnostic, Egypt). Calcium $(\mathrm{Ca})$, sodium $(\mathrm{Na})$, potassium $(\mathrm{K})$ and phosphorous $(\mathrm{P})$ were determined using colorimetric kits (BioMed, Germany). Progesterone $\left(\mathrm{P}_{4}\right)$ and estradiol 17- $\beta\left(\mathrm{E}_{2}\right)$ were analyzed using ELISA kits (Adaltis Europe, Italy). The intra -and inter-assay CV's were 9.3 and $9.7 \%$ respectively.

\section{Statistical analysis:}

Because multiple measurements per animal cannot be regarded as independent units of observation, repeated-measurements ANOVA (PROC MIXED of SAS, version 9.1; (Littell et al., 1996) was performed for serum biochemical parameters; serum estradiol 17$\beta$ and progesterone concentrations at days $0,5,10$ and 20. Animals (she-camels) were considered as the repeated effect. Treatment (control, MGA and CIDR) and time (days 0, 5, 10 and 20) were considered as the main effects in the model. Interaction between treatment and time was also included in the model. A first-order autoregressive structure [AR (1)] was the best fit and was used to account for within-animals variation. Values are presented as means with the standard errors of the mean. Significance was declared at 0.05 levels. Means were separated using Duncan multiple range test.

\section{RESULTS AND DISCUSSION}

\section{Serum biochemical parameters:}

Least square means \pm SE for the changes in shecamels' serum biochemical concentration are presented in Table (3). Overall means of serum total protein concentrations $(7.8 \pm 0.10,7.6 \pm 0.09$ and $7.6 \pm 0.09$ $\mathrm{g} / \mathrm{dl}$ ) were not different among treatment groups (control, MGA, and CIDR, respectively). There was no effect of time (days, 0, 5, 10 and 20) on serum total protein concentrations. No interactions between days and treatments were found. This finding is in agreement with previous reports on dromedary camels (Abdel-Samee and Marai, 1997; Patodkar et al., 2010; El-Harairy et al., 2010) as they reported that serum total protein concentrations were not affected significantly in dromedary camel by synchronization treatments, seasons of the year or sex of the camel.

Table 3. Changes in serum biochemical parameter during synchronization of ovulation period in dromedary she-camels in North coast of Egypt (Mean \pm SE)

\begin{tabular}{|c|c|c|c|c|c|c|}
\hline \multirow{2}{*}{ Parameters } & \multirow{2}{*}{ Treatments } & \multicolumn{5}{|c|}{ Days } \\
\hline & & $\mathbf{0}$ & 5 & 10 & 20 & Overall \\
\hline \multirow{3}{*}{$\begin{array}{l}\text { Total } \\
\text { protein ( } \\
\text { g/dl) }\end{array}$} & Control & $7.7 \pm 0.20$ & $7.9 \pm 0.20$ & $7.7 \pm 0.20$ & $7.8 \pm 0.20$ & $7.8 \pm 0.10$ \\
\hline & MGA & $7.6 \pm 0.19$ & $7.7 \pm 0.19$ & $7.5 \pm 0.19$ & $7.8 \pm 0.19$ & $7.6 \pm 0.09$ \\
\hline & CIDR & $7.6 \pm 0.19$ & $7.7 \pm 0.19$ & $7.9 \pm 0.19$ & $7.4 \pm 0.19$ & $7.6 \pm 0.09$ \\
\hline \multirow{3}{*}{$\begin{array}{l}\text { Albumin } \\
(\mathrm{g} / \mathrm{dl})\end{array}$} & Control & $4.1 \pm 0.13^{b}$ & $4.9 \pm 0.13^{\mathrm{a}}$ & $4.0 \pm 0.13^{b}$ & $4.2 \pm 0.13^{b}$ & $4.3 \pm 0.06$ \\
\hline & MGA & $4.0 \pm 0.12^{\mathrm{cd}}$ & $4.5 \pm 0.12^{\mathrm{ab}}$ & $3.9 \pm 0.12^{\mathrm{cd}}$ & $4.4 \pm 0.12^{b c}$ & $4.2 \pm 0.06$ \\
\hline & CIDR & $4.1 \pm 0.12$ & $4.4 \pm 0.12$ & $3.8 \pm 0.12$ & $4.4 \pm 0.12$ & $4.2 \pm 0.06$ \\
\hline \multirow{3}{*}{$\begin{array}{l}\text { Blood urea } \\
\text { nitrogen } \\
(\mathrm{mg} / \mathrm{dl})\end{array}$} & Control & $18.2 \pm 1.19$ & $19.5 \pm 1.19$ & $16.7 \pm 1.19^{\mathrm{B}}$ & $16.6 \pm 1.19^{\mathrm{B}}$ & $17.8 \pm 0.59$ \\
\hline & MGA & $19.8 \pm 1.09$ & $17.1 \pm 1.09$ & $16.1 \pm 1.09^{\mathrm{B}}$ & $17.9 \pm 1.09^{\mathrm{B}}$ & $17.7 \pm 0.54$ \\
\hline & CIDR & $17.6 \pm 1.09^{b}$ & $16.0 \pm 1.09^{b}$ & $24.1 \pm 1.09^{\mathrm{aA}}$ & $20.5 \pm 1.09^{\mathrm{aA}}$ & $19.3 \pm 0.54$ \\
\hline \multirow{3}{*}{$\begin{array}{l}\text { Glucose } \\
(\mathrm{mg} / \mathrm{dl})\end{array}$} & Control & $109.3 \pm 3.35^{\mathrm{bcA}}$ & $126.7 \pm 3.35^{\mathrm{aA}}$ & $103.1 \pm 3.35^{\mathrm{cdB}}$ & $110.1 \pm 3.35^{\mathrm{bcB}}$ & $112.2 \pm 1.67$ \\
\hline & MGA & $101.7 \pm 3.06^{\mathrm{cAB}}$ & $115.2 \pm 3.06^{\mathrm{abB}}$ & $117 \pm 3.06^{\mathrm{abA}}$ & $124.0 \pm 3.06^{\mathrm{aA}}$ & $114.5 \pm 1.53$ \\
\hline & CIDR & $94.6 \pm 3.06^{\mathrm{cC}}$ & $116.6 \pm 3.06^{\mathrm{abB}}$ & $116.6 \pm 3.06^{\mathrm{abA}}$ & $125.3 \pm 3.06^{\mathrm{aA}}$ & $113.32 \pm 1.53$ \\
\hline \multirow{3}{*}{$\begin{array}{l}\text { Cholesterol } \\
(\mathrm{mg} / \mathrm{dl})\end{array}$} & Control & $61.8 \pm 2.77$ & $65.4 \pm 2.77$ & $56.8 \pm 2.77$ & $61.7 \pm 2.77$ & $61.4 \pm 1.38$ \\
\hline & MGA & $62.1 \pm 2.53^{\mathrm{ab}}$ & $66.5 \pm 2.53^{\mathrm{a}}$ & $54.8 \pm 2.53^{b}$ & $59.3 \pm 2.53^{a b}$ & $60.7 \pm 1.26$ \\
\hline & CIDR & $62.1 \pm 2.53$ & $59.5 \pm 2.53$ & $56.5 \pm 2.53$ & $57.4 \pm 2.53$ & $58.8 \pm 1.26$ \\
\hline \multirow{3}{*}{$\begin{array}{l}\text { High } \\
\text { Density } \\
\text { Lipoprotein } \\
(\mathrm{mg} / \mathrm{dl})\end{array}$} & Control & $21.8 \pm 1.49$ & $21.41 \pm 1.49$ & $24.2 \pm 1.49$ & $21.3 \pm 1.49$ & $22.2 \pm 0.74$ \\
\hline & MGA & $20.9 \pm 1.36$ & $19.3 \pm 1.36$ & $20.5 \pm 1.36$ & $22.4 \pm 1.36$ & $20.8 \pm 0.68$ \\
\hline & CIDR & $20.15 \pm 1.36$ & $19.7 \pm 1.36$ & $21.76 \pm 1.36$ & $18.3 \pm 1.36$ & $20.0 \pm 0.68$ \\
\hline \multirow{3}{*}{$\begin{array}{l}\text { Aspartate } \\
\text { aminotrans } \\
\text { ferase } \\
\text { (IU/L) }\end{array}$} & Control & $21.2 \pm 0.97$ & $23.7 \pm 0.97$ & $20.7 \pm 0.97$ & $21.7 \pm 0.97$ & $21.8 \pm 0.48$ \\
\hline & MGA & $21.3 \pm 0.89$ & $24.1 \pm 0.89$ & $22.2 \pm 0.89$ & $20.4 \pm 0.89$ & $22.0 \pm 0.44$ \\
\hline & CIDR & $19.2 \pm 0.89$ & $22.1 \pm 0.89$ & $19.6 \pm 0.89$ & $21.7 \pm 0.89$ & $20.6 \pm 0.44$ \\
\hline \multirow{2}{*}{$\begin{array}{l}\text { Alanine } \\
\text { aminotrans } \\
\text { ferase } \\
\text { (IU/L) }\end{array}$} & $\begin{array}{l}\text { Control } \\
\text { MGA }\end{array}$ & $\begin{array}{c}4.8 \pm 0.54 \\
5.1 \pm 0.49^{c}\end{array}$ & $\begin{array}{c}4.6 \pm 0.54 \\
5.1 \pm 0.49^{c}\end{array}$ & $\begin{array}{c}5.3 \pm 0.54 \\
5.3 \pm 0.49^{b c}\end{array}$ & $\begin{array}{c}4.4 \pm 0.54^{\mathrm{B}} \\
6.8 \pm 0.49^{\mathrm{abA}}\end{array}$ & $\begin{array}{c}4.8 \pm 0.27^{\mathrm{B}} \\
5.5 \pm 0.24^{\mathrm{A}}\end{array}$ \\
\hline & CIDR & $4.6 \pm 0.49^{c}$ & $5.2 \pm 0.49^{c}$ & $5.3 \pm 0.49^{b c}$ & $8.1 \pm 0.49^{\mathrm{aA}}$ & $5.8 \pm 0.24^{\mathrm{A}}$ \\
\hline
\end{tabular}

${ }^{\mathrm{a}-\mathrm{d}}$ values within the same row with different letters differ $(\mathrm{P}<0.05)$.

${ }^{\mathrm{A}, \mathrm{B}}$ values within the same column with different letters differ $(\mathrm{P}<0.05)$.

$\mathrm{MGA}=$ Melengestrol acetate $(0.5 \mathrm{mg} / \mathrm{h} / \mathrm{d}) . \mathrm{CIDR}=$ Controlled internal drug release device containing $\left(1.34 \mathrm{gm} \mathrm{P}_{4}\right)$. 
Day $0=$ CIDR in, MGA feeding begins; Day $5=5$ days after CIDR removal or MGA withdrawal; Day $10=$ CIDR removal or MGA withdrawal; Day 20= day of hCG injection.

Overall means of serum albumin (Alb) concentrations $(4.3 \pm 0.06,4.2 \pm 0.06$ and $4.2 \pm 0.06$ $\mathrm{g} / \mathrm{dl})$ were not different among treatments groups (control, MGA, and CIDR, respectively). There were interactions $(\mathrm{P}<0.05)$ between treatment and days. Serum albumin (Alb) concentrations were elevated (P $<0.05)$ in control and MGA groups at day 5 (4.9 \pm 0.13 and $4.5 \pm 0.12 \mathrm{~g} / \mathrm{dl}$ ) compared to days 0,10 and 20. More importantly, albumin concentrations were at their nadir levels at day 10 that corresponds with the end of progestin treatments. These data indicate that progestins might have the potential to negatively affect animals health for a limited period of time reflected in decreased serum albumin concentrations at day 10 and elevated ALT liver enzyme activity at day 20. Other researchers (Faye et al., 1995; Chaudhary et al., 2003 and Momenah, 2014) reported increased serum immunoglobulin fraction as camels grow older and healthier and this, in part, may be due to many factors such as maturation of the lymphoid system or to parasitic infections. Plasma albumin concentrations were higher in adult healthy camels due to higher liver activities (Momenah, 2014).

Overall means of serum urea (BUN) concentrations $(17.8 \pm 0.59,17.7 \pm 0.54$ and $19.3 \pm$ $0.54 \mathrm{mg} / \mathrm{dl}$ ) of control, MGA and CIDR groups were not different during synchronization period. There were interactions $(\mathrm{P}<0.05)$ between treatment and days. At day 10, serum urea concentrations (BUN) were elevated $(\mathrm{P}<0.01)$ in the CIDR group $(24.1 \pm 1.09$ $\mathrm{mg} / \mathrm{dl})$ compared to MGA $(16.1 \pm 1.09 \mathrm{mg} / \mathrm{dl})$ and control $(16.7 \pm 1.09 \mathrm{mg} / \mathrm{dl})$ groups. Similar trend was noted at day 20. Increased blood urea nitrogen in the CIDR group at days 10 and 20 could be due to local inflammation intravaginaly caused by the CIDR implants that increased white blood cells count at these respective days (data not shown). Similar findings were reported after inserting CIDRs for 10 days in shecamels (Khalifa et al., 2011).

Overall means of serum glucose (Glu) concentrations $(112.2 \pm 1.67,114.5 \pm 1.53$ and $113.3 \pm$ $1.53 \mathrm{mg} / \mathrm{dl})$ were not different among she-camels (control, MGA, and CIDR groups, respectively). There were interactions $(\mathrm{P}<0.01)$ between treatment and days. At days 0 and 5, the control group had more serum glucose $(109.3 \pm 3.35$ and $126.7 \pm 3.35 \mathrm{mg} / \mathrm{dl})$ compared to treatment groups and this situation was reversed at days 10 and 20 where control group had less serum glucose concentrations $(103.1 \pm 3.35$ and $110.1 \pm 3.35 \mathrm{mg} / \mathrm{dl}$ ) compared to treatment groups (Table 3). These data are in agreement with those reported by Khalifa et al. (2011) and Shujait (2008). Serum glucose concentrations were lower than control during days 0 and 5 whereas at days 10 and 20 serum concentrations of glucose were higher in the progestintreated animals compared to controls. This increase in serum glucose at days 10 and 20 coincides with increased ovarian activity and readiness for ovulation and conception as a metabolic response of the animals to accommodate the ovarian activity induced by progestin treatments. Furthermore, it is vital for ovarian functions to have higher circulating concentration of glucose, whereas a negative nutrient balance can influence ovarian metabolism (Rabiee and Lean, 2000).

Overall means of serum cholesterol (Cho) concentrations $(61.4 \pm 1.38,60.7 \pm 1.26$ and $58.8 \pm$ $1.26 \mathrm{mg} / \mathrm{dl})$ were not different among treatment groups (control, MGA, and CIDR, respectively). Serum cholesterol concentrations were less in the MGA group $(54.8 \pm 2.53 \mathrm{mg} / \mathrm{dl})$ at day 10 than at days 0,5 and 20 . No differences were detected among days in cholesterol concentration in control and CIDR groups. Overall mean serum high density lipoprotein concentrations (HDL) were not different among treatment groups. In addition, there were no interactions between treatment and days.

Overall means of serum aspartate aminotransferase $($ AST $)$ concentrations $(21.8 \pm 0.48,22.0 \pm 0.44$ and $20.0 \pm 0.44 \mathrm{IU} / \mathrm{L})$ were not different among treatment groups (control, MGA, and CIDR respectively). There were no interactions between treatments and days. Overall mean serum alanine aminotransferase (ALT) concentrations were greater $(\mathrm{P}<0.05)$ in the MGA group $(5.5 \pm 0.24 \mathrm{IU} / \mathrm{L})$ and $\mathrm{CIDR}(5.8 \pm 0.24 \mathrm{IU} / \mathrm{L})$ than the control group $(4.8 \pm 0.27 \mathrm{IU} / \mathrm{L})$. At day 20 serum ALT concentration was higher $(\mathrm{P}<0.01)$ in the MGA $(6.8 \pm 0.49 \mathrm{IU} / \mathrm{L})$ and $\operatorname{CIDR}(8.1 \pm 0.49 \mathrm{IU} / \mathrm{L})$ groups than in the control group $(4.4 \pm 0.54 \mathrm{IU} / \mathrm{L})$. The variations in the concentrations of serum enzymes AST and ALT in the dromedary camels may be attributed to many factors such as seasons of the year that plays a major role in transaminase activities, which is in agreement with the findings of Abdel-Samee and Marai (1997) and El-Harairy et al. (2010). They reported significant effects of different seasons on AST and ALT enzyme activities in dromedary she-camels that were noted during summer than in winter, autumn or spring. Furthermore, liver functions may be partially affected by heat stress during the non-breeding season or estrus period (Abdel-Samee and Marai, 1997). Similar findings have been reported in male dromedaries (Ahmadi, 2001). Also AST and ALT enzyme activities were affected by differences in feed intake (Westerbacka et al., 2005) and liver enzymes are known to be lower in blood when the nutrient intake is high (Oni et al., 2006). The increased serum transaminases might indicate impairment in some muscle and liver cells due to rapid gluconeogenesis associated with pregnancy. Both enzymes were found to be involved in gluconeogenesis (Krebs, 1966).

\section{Serum mineral concentrations}

Least square means \pm SE for changes in shecamels' serum mineral concentrations are presented in Table (4). Overall means of serum calcium (Ca) concentrations $(10.2 \pm 0.96,11.2 \pm 0.87$ and $12.1 \pm$ $0.87 \mathrm{mg} / \mathrm{dl}$ ) were not different among treatment groups 
(control, MGA, and CIDR, respectively). There was no effect of time (days, 0, 5, 10 and 20) on serum calcium concentrations. Also, no interactions between days and treatments were detected.

Overall means of serum sodium (Na) concentrations $(116.3 \pm 6.58,120 \pm 6.01$ and $117.4 \pm$ $6.01 \mathrm{mEq} / \mathrm{l})$ were not different among treatment groups (control, MGA, and CIDR, respectively). There was no effect of time (days, 0, 5, 10 and 20) on serum sodium concentrations. No interactions between days and treatments were detected. This finding is in agreement with previous reports on dromedary camels (Rezakhani et al., 1997; Khalid and AL-Busadah, 2007) as they reported that serum calcium and sodium concentrations were not affected significantly in dromedary camel by synchronization treatment, breed or sex of camels.

Table 4. Changes in serum calcium (Ca), phosphorus (P), sodium (Na) and potassium (K) during synchronization of ovulation period in dromedary she-camels in the North western Coast of Egypt

\begin{tabular}{|c|c|c|c|c|c|c|}
\hline \multirow{2}{*}{ Parameters } & \multirow{2}{*}{ Treatments } & \multicolumn{4}{|c|}{ Days } & \multirow{2}{*}{ Overall } \\
\hline & & $\mathbf{0}$ & 5 & 10 & 20 & \\
\hline \multirow{3}{*}{$\mathrm{Ca}(\mathrm{mg} / \mathrm{dl})$} & Control & $10 \pm 1.92$ & $10.1 \pm 1.92$ & $11.1 \pm 1.92$ & $9.8 \pm 1.92$ & $10.2 \pm 0.96$ \\
\hline & MGA & $10.5 \pm 1.75$ & $12.5 \pm 1.75$ & $10.7 \pm 1.75$ & $11.1 \pm 1.75$ & $11.2 \pm 0.87$ \\
\hline & CIDR & $14.6 \pm 1.75$ & $12.1 \pm 1.75$ & $10.7 \pm 1.75$ & $11.1 \pm 1.75$ & $12.1 \pm 0.87$ \\
\hline \multirow{3}{*}{$\mathrm{P}(\mathrm{mg} / \mathrm{dl})$} & Control & $3.4 \pm 0.26$ & $3.4 \pm 0.26$ & $3.8 \pm 0.26$ & $3.7 \pm 3.35$ & $3.6 \pm 0.13$ \\
\hline & MGA & $3.3 \pm 0.26^{\mathrm{b}}$ & $3.3 \pm 0.24^{b}$ & $3.5 \pm 0.24^{b}$ & $4.7 \pm 3.06^{\mathrm{a}}$ & $3.7 \pm 0.12$ \\
\hline & CIDR & $2.8 \pm 0.24^{c}$ & $3.5 \pm 0.24^{b c}$ & $4.1 \pm 0.24^{\mathrm{ab}}$ & $4.6 \pm 0.24^{\mathrm{a}}$ & $3.8 \pm 0.12$ \\
\hline $\begin{array}{l}\mathrm{Na} \\
(\mathrm{mEq} / \mathrm{L})\end{array}$ & Control & $132.6 \pm 13.16$ & $111.3 \pm 13.16$ & $101.1 \pm 13.16$ & $120.2 \pm 13.16$ & $116.3 \pm 6.58$ \\
\hline $\mathrm{Na}$ & MGA & $116.9 \pm 12.02$ & $129.3 \pm 12.02$ & $110.1 \pm 12.02$ & $123.7 \pm 12.02$ & $120.0 \pm 6.01$ \\
\hline$(\mathrm{mEq} / \mathrm{L})$ & CIDR & $114.6 \pm 12.02$ & $115.8 \pm 12.02$ & $118.3 \pm 12.02$ & $121.0 \pm 12.02$ & $117.4 \pm 6.01$ \\
\hline $\mathrm{K}(\mathrm{mEq} / \mathrm{L})$ & Control & $3.2 \pm 0.32$ & $3.6 \pm 0.32$ & $3.6 \pm 0.32$ & $3.4 \pm 0.32$ & $3.4 \pm 0.16^{\mathrm{B}}$ \\
\hline \multirow{2}{*}{$\mathrm{K}(\mathrm{mEq} / \mathrm{L})$} & MGA & $2.9 \pm 0.29^{c}$ & $3.1 \pm 0.29^{c}$ & $3.6 \pm 0.29^{b c}$ & $4.2 \pm 0.29^{\mathrm{ab}}$ & $3.5 \pm 0.14^{\mathrm{B}}$ \\
\hline & CIDR & $3.4 \pm 0.29^{\mathrm{cd}}$ & $3.7 \pm 0.29^{\mathrm{cd}}$ & $4.6 \pm 0.29^{\mathrm{ab}}$ & $5.3 \pm 0.29^{a}$ & $4.2 \pm 0.14^{\mathrm{A}}$ \\
\hline
\end{tabular}

${ }^{a-d}$ values within the same row with different letters differ $(p<0.05)$.

${ }^{A, B}$ values within the same column with different letters differ $(\mathrm{p}<0.05)$.

MGA $=$ Melengestrol acetate $(0.5 \mathrm{mg} / \mathrm{h} / \mathrm{d})$.

$\mathrm{CIDR}=$ Controlled internal drug release device containing (1.34 gm P4).

Day $0=$ CIDR in, MGA feeding begin;

Day $5=5$ days after CIDR removal or MGA withdrawal;

Day $10=$ CIDR removal or MGA withdrawal;

Day $20=$ day of hCG injection.

Overall means of serum phosphorus (P) concentrations $(3.6 \pm 0.13,3.7 \pm 0.12$ and $3.8 \pm 0.12$ $\mathrm{mg} / \mathrm{dl})$ were not different among treatment groups (control, MGA, and CIDR, respectively). There was no effect of time (days, 0, 5, 10 and 20) on serum phosphorus concentrations but there were interactions $(\mathrm{P}<0.05)$ between days and treatments where there was a tendency to increase $\mathrm{P}$ concentration with days particularly in the treated groups. Animals in the MGA and CIDR groups had the highest serum $\mathrm{P}$ concentrations $(4.7 \pm 0.36$ and $4.6 \pm 0.24 \mathrm{mg} / \mathrm{dl})$ at day 20 compared to days 0,5 and 10 . Increased phosphorus might be attributed to the transformation of ATP to ADP during augmentation of bioactivity of various physiological processes in the body such as follicular development (Eissa, 1996). Results of the present study agree with the findings that levels of serum phosphorus (Table 4), estradiol (Figure 1) and glucose (Table 3) increased in CIDR and MGA groups at day 20. Omer et al. (2000) and Abu Damir (1998) reported that serum phosphorus (P) level is affected by age, breeding season and grassing (availability of plants rich in minerals) or feeding.

Overall means of serum potassium (K) concentrations were different $(\mathrm{P}<0.01)$ among treatment groups where CIDR group had more (4.2 \pm
$0.14 \mathrm{mEq} / \mathrm{l})$ potassium than the control and MGA (3.4 \pm 0.16 and $3.5 \pm 0.14 \mathrm{mEq} / \mathrm{l})$ groups. There was a time (days, 0, 5, 10 and 20) effect $(\mathrm{P}<0.05)$ but no interaction was detected between days and treatments on serum $(\mathrm{Na})$ concentrations. The highest serum $\mathrm{K}$ concentrations were recorded in the CIDR group at days $10(4.6 \pm 0.29)$ and $20(5.3 \pm 0.29 \mathrm{mEq} / \mathrm{l})$. This increase in serum $(\mathrm{k})$ may be attributed to the increase of progesterone which increase the ability to retain potassium (Elabida et al., 2011).

\section{Serum Estradiol 17- $\beta\left(E_{2}\right)$ and progesterone $\left(P_{4}\right)$ concentrations}

Changes in serum estradiol 17- $\beta$ and progesterone concentrations in she-camels are presented in Figure 1. The differences in overall means serum estradiol 17- $\beta$ concentration $(52.6 \pm 7.31,46.1 \pm 6.92$ and $51.3 \pm 7.02$ $\mathrm{pg} / \mathrm{ml}$ ) between treatment groups were not significant. There was no effect or interaction between treatments and days $(0,5,10$ and 20) on serum concentrations of estradiol 17- $\beta$. Despite the fact that there was no time and treatment interactions, MGA and CIDR groups that received the progestin treatments had slightly lower $E_{2}$ concentrations at days 5 and 10 compared to controls (Figure 5), and this trend was reversed at day 20 after 
MGA feeding withdrawal and CIDR removal with the highest $\mathrm{E}_{2}$ levels recorded in CIDR treated animals $(89.6 \pm 14.62 \mathrm{pg} / \mathrm{ml})$. The numerical changes in serum estradiol $17 \beta$ concentration observed in the present study are clearly attributed to the changes in ovarian kinetics in control group compared with MGA and
CIDR groups during the synchronization period. Progestin treatments inhibited the ovarian growth of newer follicles and thereby slightly decreased estradiol concentration during the 10 days of progestin treatment period. Serum estradiol increased at day 20 after removal of CIDR and withdrawal of MGA feeding.
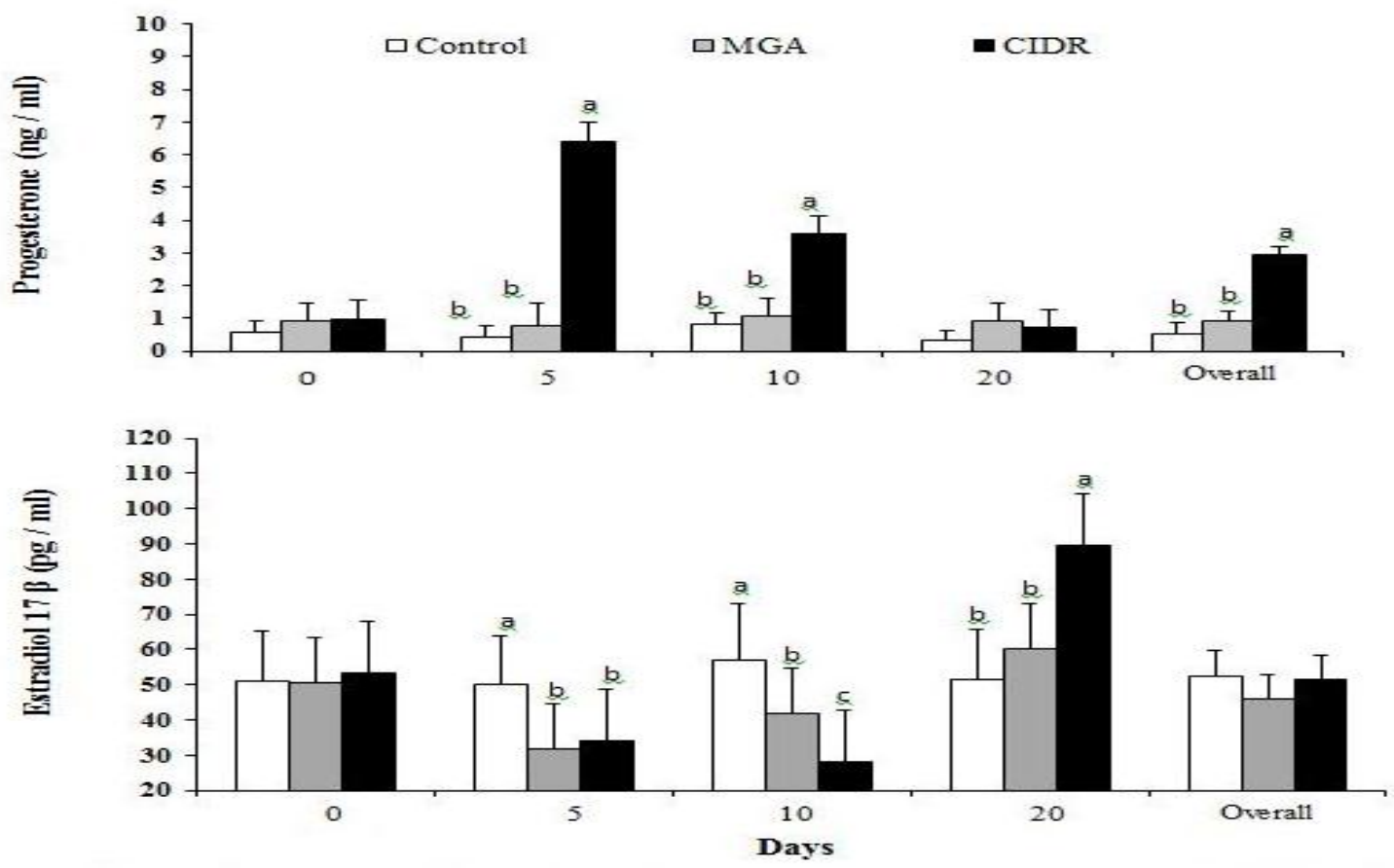

Figure 1. Concentrations of serum progesterone $(\mathrm{ng} / \mathrm{ml})$ and estradiol-17及 (pg/ml) at days $0,5,10$ and 20 of induction of ovulation protocols in she-camels

MGA $=$ Melengestrol acetate $(0.5 \mathrm{mg} / \mathrm{h} / \mathrm{d})$.

CIDR $=$ Controlled internal drug release device containing $\left(1.34 \mathrm{gm} \mathrm{P}_{4}\right)$.

Day $0=$ CIDR in, MGA feeding begin; Day $10=$ CIDR removal or MGA withdrawal;

Day $15=5$ days after CIDR removal or MGA withdrawal; Day $20=$ day of hCG injection

Overall means of serum progesterone concentrations of CIDR group $(2.93 \pm 0.28 \mathrm{ng} / \mathrm{ml})$ was significantly greater $(\mathrm{P}<0.01)$ than that of control and MGA groups $(0.53 \pm 0.33,0.92 \pm 0.29 \mathrm{ng} / \mathrm{ml})$. There were interactions $(\mathrm{P}<0.05)$ between treatment and days. Serum $\mathrm{P}_{4}$ concentrations in the control and MGA-fed animals were not affected with progression of time during the experimental period (Figure 1). However, CIDR group had elevated serum progesterone $(6.42 \pm 0.62 \mathrm{ng} / \mathrm{ml})$ at day 5 (mid of treatment time) that was declined to $(3.58 \pm 0.55$ $\mathrm{ng} / \mathrm{ml}$ ) yet remained elevated by the CIDR removal time at day 10 and continued to decrease to $(0.73 \pm$ $0.55 \mathrm{ng} / \mathrm{ml})$ concentration comparable to control $(0.31$ $\pm 0.70 \mathrm{ng} / \mathrm{ml})$ and MGA $(0.93 \pm 0.55 \mathrm{ng} / \mathrm{ml})$ groups at day 20. Homeida and Al-Mubarak (2009) and Khalifa et al. (2011) noted that administration of progesterone as intravaginal device in camels produced significantly higher concentration of progesterone in peripheral circulation as a result of effective absorption from vagina of the camel depending on the dose. Synthetic progestin (MGA) did not increase the natural progesterone in the peripheral circulation, however, it mimics its function. Removal of devices or implant or stoppage of injections of progesterone resulted in rapid decline of the hormone in a way expected to follow a biexponentail curve with a half-life of $26 \mathrm{~min}$ (AlBusadah and Homeida, 2004). Comparable studies have been performed in cows (Narasimha and Suraprakasam, 1992) and ewes (Scudamore et al., 1992) using intravaginal devices of progesterone. The type of device or dosage of steroid which might produce response such as follicular growth accelerate ovum development (Thompson et al., 1990 and Scudamore et al., 1992).

\section{CONCLUSION}

It could be concluded that induction of ovulation in dromedary she-camels with either natural (CIDR) or synthetic progestin (MGA) source exerted no deleterious effects on animal health and produced comparable results and could be used with no limitations in further synchronization treatments. 


\section{ACKNOWLEDGEMENT}

This study has been achieved within the PROCAMED project funded by European Union within the program ENPI-CBC-MED, reference number I.B/1.1/493. The content of the present document is under the responsibility of the PROCAMED partners and could not be considered as the position of European Union.

\section{REFERENCES}

Abdel-Samee A. M. and I. F. M. Marai, 1997. Daily body gain and some related physiological and biochemical changes in dromedary camels as affected by hot climate. International Conference on Animal Production and Health, pp. 331-339.

Abu Damir H., 1998. Mineral deficiencies, toxicities and imbalances in the camel (Camelus dromedarius) a review. Veterinary Bulletin., 68 (10): 1103- 1119.

Ahmadi, E. A., 2001. Physiological and reproductive studies in camels. Ph.D. Thesis, Faculty of Agriculture, Zagazig University, Zagazig, Egypt.

Al-Busadah K. A. and A. M. Homeida, 2004. Pharmaco kinetics of progesterone in (dromedary Camels). Research of Veterinary Science,(8): 245247.

Amundson J. L., H. U. Mader and R. J. QS, 2006. Environmental effects on pregnancy rate in beef cattle. Journal of Animal Science, (84): 3415- 3420.

Chaudhary Z. I., J. Iqbal and J. Rashid, 2003. Serum protein electrophoretic pattern in young and adult camels. Australian Veterinary, (81): 625-626.

Claypool D.W., F.W. Adams and H.W. Pendell and N. A. Hartman, 1975. Relation between copper level in blood plasma and liver of cattle. Journal of. Animal Science, (41): 911-914.

Eissa H. M., 1996. Concentrations of steroids and biochemical constituents in follicular fluid of buffalo cows during different stages of the oestrous cycle. British Veterinary, (152):573-581.

Elabida B., A. Edwards, A. Salhi, A. Azroyan, H. Fodstad, P. Meneton, A. Doucet, M. Bloch-Faure and G. Crambert, 2011. Chronic potassium depletion increases adrenal progesterone production that is necessary for efficient renal retention of potassium. International of Kidney Science, (80): 256-262.

El-Harairy M. A., A. E. Zeidan, A. A. Afify, H. A. Amer, 2010. Ovarian activity, biochemical changes and histological status of the dromedary she camel as affected by the different seasons of the year. Natural Science, (8): 54-65.

Farah, Z., 1996. Camel milk properties and products. St. Gallen, Switzerland: SKAT.

Faye B. R., J. P. Chacornac and P. Soubre, 1995. Metabolic profiles and risks of diseases in camels in temperate conditions. Comp. Biochem. Physiology, (112): 67-73.
Homeida A. M. and A. I. Mubarak, 2009. Effect of administration of different progesterone formulations on the plasma progesterone concentrations in she-camel. Research of Pharmacology, (1): 19 - 21.

Khalid A and A. AL-Busadah, 2007. Some biochemical and hematological indices in different breeds of camels in Saudi Arabia. Basic and Applied Science, (8): 131-142.

Khalifa, M. A. A, 2011. Manipulation of postpartum fertility in one-Humped She-Camels during the non-breeding season under semi-aria condition. PhD. Thesis, Faculty of Agriculture, Alexandria University, Egypt.

Krebs H. I., A. T. Gascoyne and M. N. Brenda, 1966. Generation of Extramitochondrial Reducing Power in Gluconeogenesis. Biochem Science, (102): 275282.

Littell R. C., G. A. Milliken, W. W. Stroup and R. D. Wolfinger, 1996. SAS System for Mixed Models. SAS Inst. Inc., Cary, NC.

Momenah M. A., 2014. Some blood parameters of one humped she-Camels (Camelus dromedaries) in response to parasitic infection. Life Science, (11): 118-123.

Narasimha R. V. and A. M. Suryaprakas, 1992. Induction of synchronized estrus and fertility in anestrous Zebux Taurus crossed cow's .Theriogenology, (36): 123-126.

NRC. National Research Council, 1985. Nutrition requirements of sheep.6th Rev. Ed, national Academy Press, washington, D. C. USA.

Omer S. A., M. E. Salawa, H. A. Khougali and H. A. Gussey, 2000. Studies on some biochemical and hematological indices of Sudanese camels (Camelus dromedarius).Veterinary Bulletin, (10): $168-175$.

Oni A. O., C. F. Onwuka, O. O. Oduguwa, O. S. Onifade, O. M Arigbede and J. E, Olatunj, 2006. Utilization of Citrus pulp based diets and enterolobium cyclocarum foliage (Jacq. Griseb) by West African Dwarf goats. Animal Veterinary Advanced, (5): $814-818$.

Osman T. E and K. A. Al-Busadah, 2000. Effects of age and lactation on some biochemical constituents of camel blood in Saudi Arabia. Camel Practice and Research, (2): 149 - 152.

Patodkar V. R., A. P. Somkuwar and S. Parekar, 2010. Influence of Sex on certain biochemical parameters in Nomadic Camels (Camelus dromedarius) nearby Pune, in Maharashtra. Veterinary World, 3 (3): 115-117.

Rabiee A. R. and I. J. Lean, 2000. Uptake of glucose and cholesterol by the ovary of sheep and cattle and the influence of arterial LH concentrations. Animal Reproduction Science, (64): 199 -209.

Rezakhani A., S. N. Habibabadi and M. M. Ghojogh, 1997. Studies on normal hematological and biochemical parameters of Tuurkmen camel in Iran. Camel Practice and Research, (4): 41- 44. 
Scudamore C. L., J. J. Robinson, R. P. Aitken and I. S. Robertson, 1992. Comparison of priming with 2 dosages of fluorogestone acetate in pessaries on the quality of embryos recovered from superovulated ewes. Theriogenology, (37): 445 - 456.

Shujait A. N., A. A. Nafees and D. E. Zia-ur-Rahman, 2008. Metabolite contents of blood serum and fluid from small and large sized follicles in dromedary camels during the peak and the low breeding seasons. Animal Reproduction. Science, (108): 446 $-456$.

Skidmore J. A., G. P. Adams and M. Billah, 2009. Synchronization of ovarian follicular waves in the dromedary camel (Camelus dromedarius). Animal Reprod Science, (114): 249-255.
Thompson F. N., 2001. Hormones affecting reproduction .Veterinary pharmacology and Therapeutics. In: Adams, H. R. (Ed.) Lowa state University press. pp: 612-625.

Thompson J. G. E., A. C. Simpson, R. W. James, and H. R. Tervit, 1990. The application of progesterone containing CIDR devices to superovulated ewes. Theriogenology, (33): 1297-1304.

Westerbacka J., K. Lammi, A. Hakkinen, A. Rissanen, I. Salminen, A. Aro and H. Yki-Jarvinen, 2005. Dietary fat content modifies liver fat in overweight nondiabetic subjects, Endocrinology, (90): 280284.

تأثير مصدر البروجستين على بعض مكونات الام البيوكميائية لإناث الإبل وحيدة السنام خلال مرحلة حفز الإباضة في

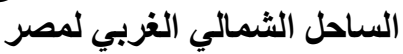

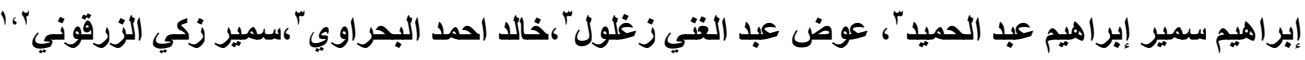

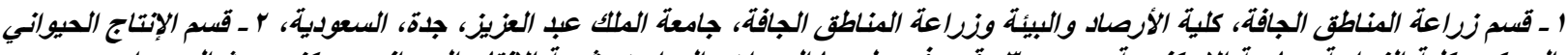

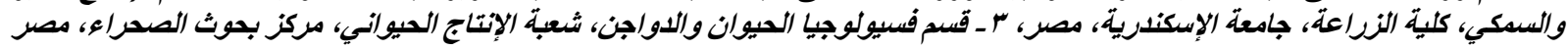

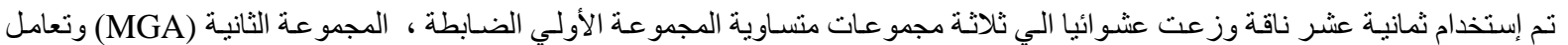

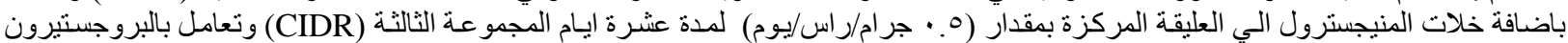

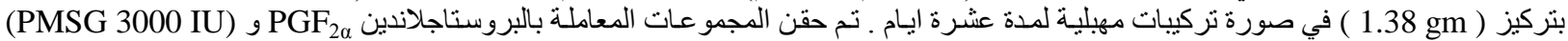

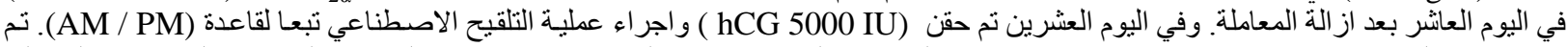

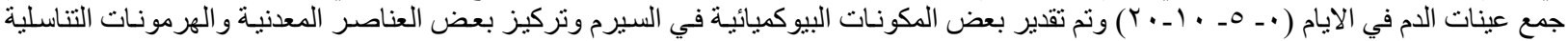

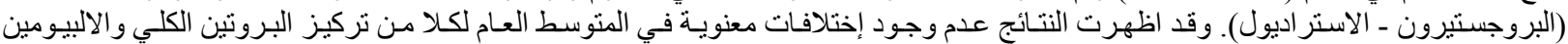

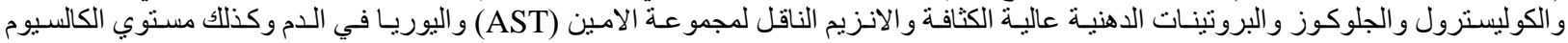

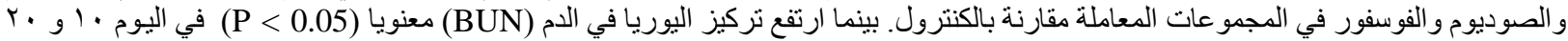

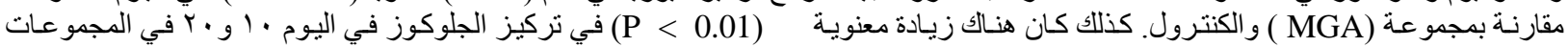

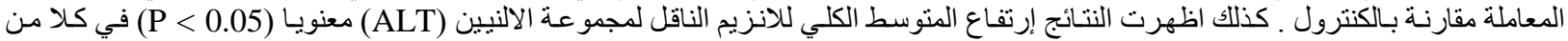

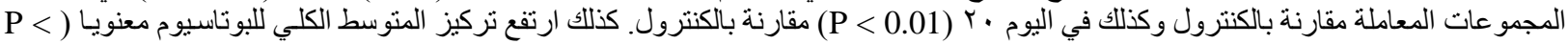

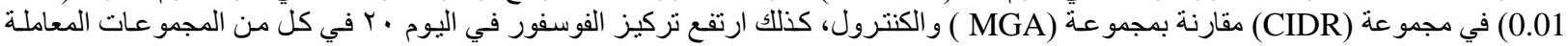

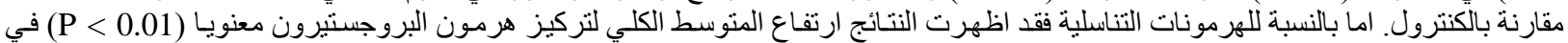

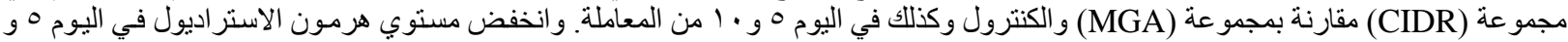

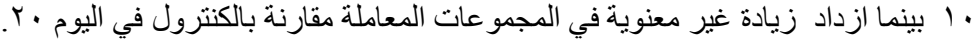

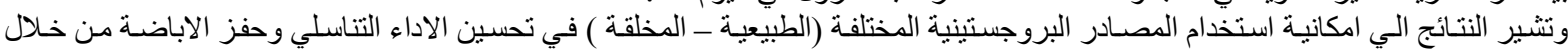

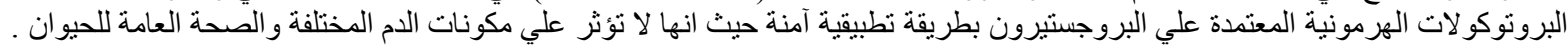

